\title{
Geophysical Characterization of Oil Spill Sites in Parts of Niger Delta Using Electrical Resistivity Tomography, Southern Nigeria
}

\author{
Ayibawari O, Egai $^{1^{*}} \quad$ Ebiegberi Oborie ${ }^{2}$ \\ 1.Department of Geology, Niger Delta University, Nigeria \\ 2.Department of Geology, Niger Delta University, Amassoma \\ Corresponding Author's Postal Address; C/o Egai Ayibawari Obiene \\ Department of Geology, Faculty of Science, Niger Delta University, Nigeria \\ P.M.B 071, Yenagoa, Bayelsa State. Post code 300283
}

\begin{abstract}
Geophysical survey using 2D resistivity tomography was acquired to characterize two hydrocarbon impacted sites of Ikarama and Kalaba. In the impacted sites six (6) 2D resistivity imaging profiles were carried out to understand the resistivity distribution as basis for interpreting the depth and lateral extent of contamination. Additionally, two (2) 2D resistivity imaging profiles were also carried out in the un-impacted sites to serve as control. Surface geophysical survey was acquired using ABEM SAS 1000 terammeter set with electrode constant separation of 6 step array system with a maximum electrode separation of five metres in a traverse of 100 meters. The 2D resistivity imaging data was interpreted using Res2Div. The results indicated the distribution of electrical resistivity within the subsurface. The resistivity sections were displayed in shades of rainbow colours. The values for the models range from $1.05 \Omega \mathrm{m}$ to $11472 \Omega \mathrm{m}$, the resistivity models show a general increase of resistivity with depth relative to the control points. The $2 \mathrm{D}$ resistivity models correlate well with the borehole logs as top soil, clay, sandy clay and sand. Also, some of the 2D models indicate increases in resistivity with depth. They also show interaction of water interplaying with the contaminant plume. The resistivity range of $0.005 \Omega \mathrm{m}$ to $11.3 \Omega \mathrm{m}$ which occurred from the surface is interpreted as top soil. Immediately underlying this layer is a region of high resistivity with range of $9.4 \Omega \mathrm{m}$ to $78.1 \Omega \mathrm{m}$ which indicate petroleum contamination that may have seeped through the clay horizon to the sandy layer. This may be due to the fact that the invading crude oil may have exceeded the retention capacity of the porous medium hence allowing crude oil to spread to other zones of high hydraulic conductivity materials. In addition, it is also possible that the clay bodies were not localized. Superimposition of the main profile generated to monitor petroleum contaminant and the control profiles established a remarkably difference showing the main profiles increases of resistivity with depth, while the resistivity of the control profiles decreases with depth and possibly with materials highly resistive at the top. The study established that biodegradation increases as the depth decreases. The characterization of high resistivity with decrease in depth of the impacted sites were due to oil spill contamination whereas, decrease in resistivity with respect to depth is agreeable to non-petroleum site having materials that were restive at the top. The study pointed out hydrocarbon contamination of the both sites between shallow depths of $3 \mathrm{~m}$ to $7 \mathrm{~m}$ which may infiltrate to change the composition of near surface aquifers in the locality. Therefore, more geophysical studies is recommended in this area.
\end{abstract}

Keywords: Electrical Resistivity Tomography, Oil spill, Geophysical Characterization

DOI: $10.7176 / \mathrm{JEES} / 11-2-08$

Publication date: February $28^{\text {th }} 2021$

\section{Introduction}

The exploration and exploitation activities of the petroleum and gas industries generate a large volume of waste. A greater percentage of this waste percolates into the subsurface, depending on the kind of rocks which remains a significant environmental problem. The complex relationship among pollutant, geochemical and hydrological conditions and micro-organism involved in contamination degradation must be understood. In addition, monitoring tools are needed to observe the migration or removal of the contaminant mass, the rate of bio-degradation and the possible development of more toxic intermediate substances. As such intrinsic research and adaptive technologies and method are required to localize contaminated zones and to control remediation processes in the subsurface. The geophysical methods such as 1D Schlumberger and 2D Wenner resistivity method had frequently employed in the characterisation of contaminated zones in the subsurface (Sauck et al., 1998). This method has proven profusely useful and adequate over the years in delineating lateral and vertical geo-electrical layers in contaminated zones both in area and in depth (Atekwana et al 2000, 2002, Werkema et al 2003 and Sauck et al 1998). The migration and dispersal of crude oil in the environment seems to be faster with rainfall depending on the geology which is dependent to the land forms (Adepelumi et al., 2006). Hydrocarbons, often exhibit very high resistivity behaviour in natural environment but change to conductive behaviour with time due to biodegradation (bacterial activities and other biological processes) producing carbonic and organic acids, which contribute to enhancing the conductivities Werkema et al., (2003). Sauck (2000) also confirmed that, increase in resistivity has mostly been 
achieved in laboratory environments while decrease in resistivity are predominant in the field where the oil spill has been exposed to chemical interactions. Ikarama and Kalaba are two hydrocarbon impacted Communities in Okordia- Zarama clan of Yenagoa Local Government Area of Bayelsa State. Due to the hydrocarbon impact, groundwater and soil contamination is ubiquitous. In order to provide an understanding of the impacts of this spills, $2 \mathrm{D}$ resistivity tomography were carried out to interprete the basis of contamination on the groundwater and subsurface Stratigraphy. The specific objective of this paper is to characterize contamination of soil and groundwater in the current study areas.

\section{Description and Physiography of the Study Area}

The study area is Okordia -Zarama clan of Yenagoa Local Government Area of Bayelsa State. It is enclosed in the Niger Delta Sedimentary Basin. It lies within latitude N05 08'33.6' and longitude E006 $26^{0}$ ' 32.8'". It is accessible by the East West Federal way cycling Communities of Zarama, Okordia, Ikarama, Kalaba and Akumoni just to mention but are few. Network of crude oil pipeline both on the surface and underground manifold also known as point and flow stations can be found in this area. It is on the rain forest of the Niger Delta. The Taylor creek is the notable River channel in the study area which serves as a tributary to River Nun and empties into the Atlantic Ocean. The Niger Delta constitutes an advance of terrestrial deposits into high energy marine environment. According to Short and Stauble, 1967 deposition of the Niger Delta occurs simultaneously under fully terrestrial (fluviatile) conditions interplaying between terrestrial and marine conditions. On these premise three stratigraphic units were identified they are Benin Formation (youngest), Agbada and Akata Formations. The Benin Formation is aquiferous which is highly porous and permeable containing massive sandstone with shale inter-beds which are assume to be braided stream origin. There are a lot of studies which have reported of the Benin Formation stressing it aquiferous capacity such studies includes Short and Stauble, 1967; Etu-Efeotor, 1981, Udom et al., 1998; EtuEfeotor and Michalski, 1989; Offodile, 1992 etc. The age of Benin Formation range from Recent to Miocene. The transition Agbada Formation consist of shale and sandstone sequence represent Delta front deposit and distributaries of channel and Deltaic simple source. The sand and sandstone represent point bar deposit channels fills or crevasse splays, whereas, the shale represent back swamps deposit ( Frankl and Cordy, 1967). These Formations are stratigraphically superimposed in time and range. The Agbada Formation is Eocene of age. The Akata Formation is the lowest unit and the oldest Formation of the Tertiary Niger Delta sequence. The marine Akata Formation is a continuous shale sequence and the shale is medium to dark grey in colour. The shale is less compressed and sometime has lenses of irregular elevated pressures siltstone or fine grained sandstone. The Formation ranges in thickness from 600 to $6000 \mathrm{~m}$. The Akata Formation is rich in Foraminifera. It is believed to be the source of the Niger Delta stratigraphic system (Weber and Daukoru, 1975). The Akata Formation is parallic in age.

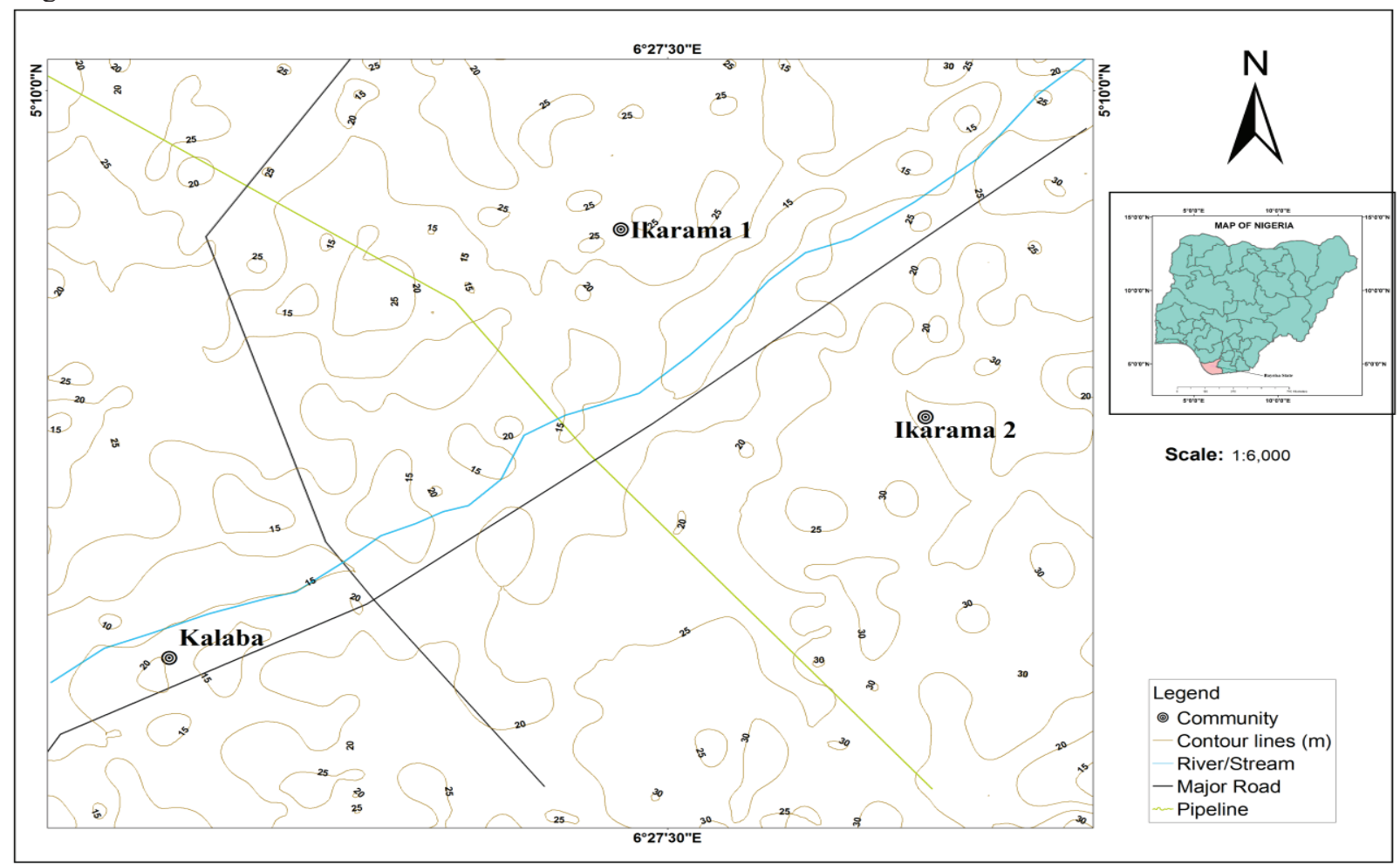

Fig 1: Description map of the study area 


\section{Materials and Method of Study}

The Wenner array configuration was used, the spacing between each electrode is identical. Four equally spaced electrodes were utilized in the transverse; two of the equally spaced collinear electrodes were the current electrodes. The inner two were located at the Centre of the array and their separation is $1 / 3$ of the total array length. Nine (9) stations were transverse using the Wenner alpha Configuration. Six 2D resistivity imaging profiles were carried out in the impacted site and two profiles were taken in the un-impacted site to understand the resistivity distribution. Data analysis from the field was converted using DAT files Erigraph (RES2DINV) which has a version 2.7 or higher for file conversion? It was primarily designed to facilitate geophysical presentation of CVES data 2D, DC, resistivity surveying and associated inverted model sections. The apparent resistivity was plotted as pseudo section in colours such as green, blue and red etc. or grey scale. The software calculates the expected field curve from the model. The program then modified this model until the calculated field data matches the actual field data

\section{Results and Discussion}

Figures 2 to 10 represent 2D models of electrical resistivity imaging (tomography) of the subsurface. Figures 2 to 7 models were generated from the impacted sites. In addition figures 8 to 10 are models which were generated in the un-impacted sites. Distribution of electrical resistivity within the subsurface the resistivity sections are displayed in shades of rainbow colours. The values for the models range from $1.05 \Omega m$ to $11472 \Omega m$ the resistivity models show a general increase of resistivity with depth relative to the control points. The $2 \mathrm{D}$ resistivity models correlate well with the borehole logs as top soil, clay, sandy clay and sand. Some of the 2D models indicate increases in resistivity with depth. The models also show interaction of water interplaying with the contaminant plume. The resistivity range of $0.005 \Omega \mathrm{m}$ to $11.3 \Omega \mathrm{m}$ which occurred from the surface is interpreted as top soil. Immediately underlying this layer is a region of high resistivity with range of $9.4 \Omega \mathrm{m}$ to $78.1 \Omega \mathrm{m}$ were indicate of petroleum contamination that have seeped through the clay horizon to the sandy layer. This was evident from the invading crude oil which became saturated hence allowing it to spread to other zones with high hydraulic conductivity materials. In addition, it is also possible that the clay bodies were not localized. The model below (Fig 2) shows subsurface resistivity distribution of $8.58 \Omega \mathrm{m}$ to $11472 \Omega \mathrm{m}$ displaying colorations of blue, light blue, light green, yellow, red and purple was obtained etc. A resistivity distribution of $8.858 \Omega \mathrm{m}$ with a depth of $0-1.25 \mathrm{~m}$ was interpreted as top soil, $23.0 \Omega \mathrm{m}$ with depth of $3.2 \mathrm{~m}$ light blue indicated suspected hydrocarbon plume with porous media such as clay with interaction of microbial loads interpreted as aged pollution. Underlying this layer resistivity of $66.6 \Omega \mathrm{m}$ to $187 \Omega \mathrm{m}$ at depth range of $9 \mathrm{~m}$ to $9.8 \mathrm{~m}$ deep blue to light green coloration is an indication of clay grading to sand or probably sandy clay. Underlying the sandy clay layer is a region of fine to coarse sand with resistivity range of $523 \Omega \mathrm{m}$ to $11472 \Omega \mathrm{m}$ and depth of $9.8 \mathrm{~m}$ to $17.5 \mathrm{~m}$ which suggest aquiferous layer and have potentials for ground water exploration. However, the groundwater is polluted with hydrocarbon plume to a depth of $5 \mathrm{~m}$ in this location

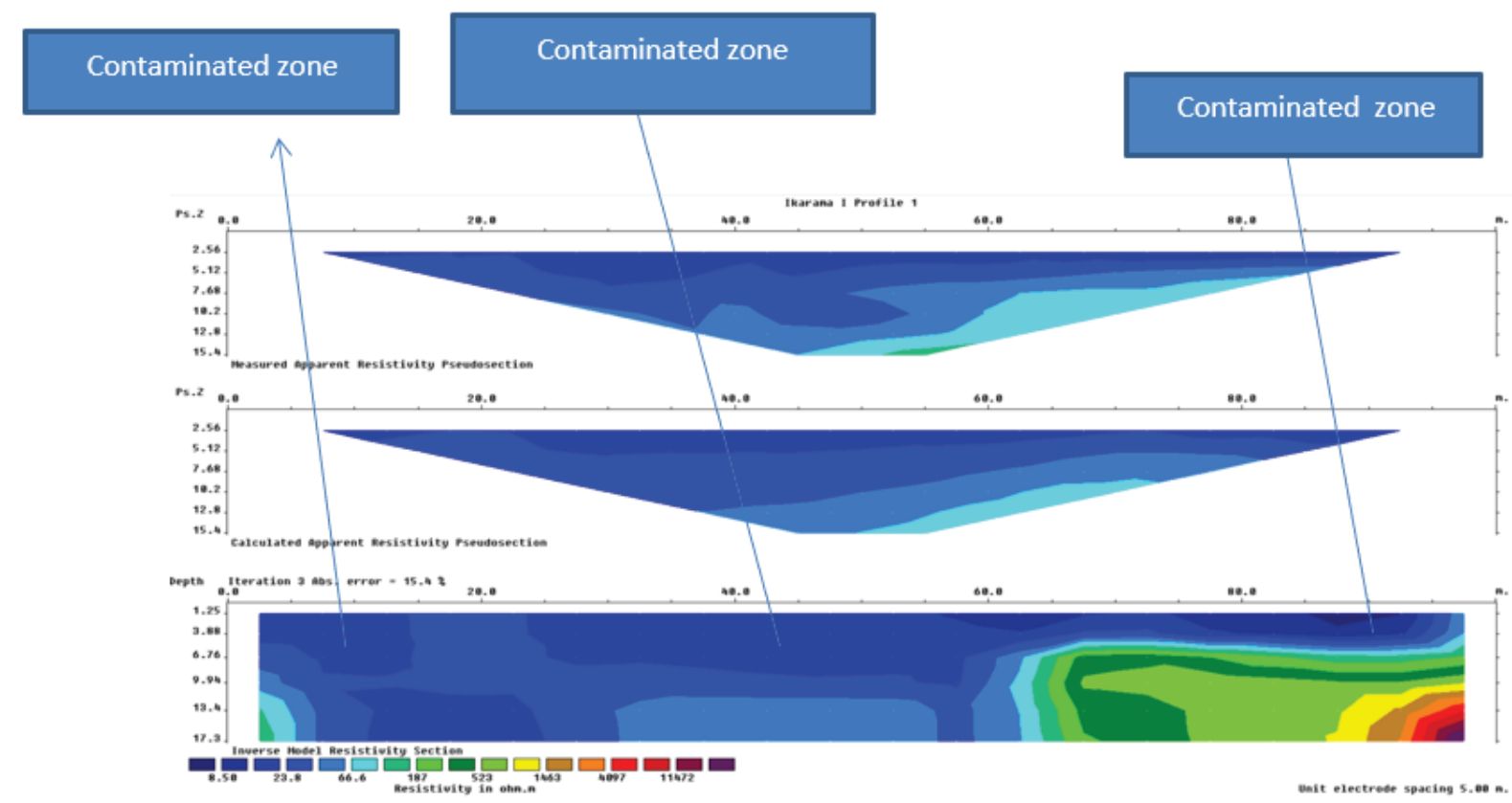

Fig 2: 2D profile of subsurface resistivity distribution at Ikarama 
Table 1: 2D profile of subsurface resistivity distribution at Ikarama

\begin{tabular}{|l|l|l|l|l|l|}
\hline LAYERS & Resistivity & Depth range & Average thickness & Interpreted lithology & Remarks \\
\hline Layer 1 & 8.58 & $0-1.25$ & 1.25 & Topsoil & \\
\hline Layer 2 & 23.0 & $1.25-3.2$ & 1.95 & Clay & Aged pollution \\
\hline Layer 3 & $66.6-187$ & $9-9.8$ & 0.8 & Sandy clay & \\
\hline Layer 4 & $523-4997$ & $9.8-17.3$ & 7.5 & Fine - coarse sand & \\
\hline
\end{tabular}

The model of Figure 3 shows subsurface resistivity distribution of $1.05 \Omega \mathrm{m}$ to $957 \Omega \mathrm{m}$ and depth of 1.25 to $17.3 \mathrm{~m}$ was delineated in profile-3 of the impacted site. A resistivity of $1.05 \Omega \mathrm{m}$ for a $1.25 \mathrm{~m}$ thick layer is interpreted as the top soil which is rich in surface organic materials. A resistivity distribution of $2.79 \Omega \mathrm{m}$ to 19.5 $\Omega \mathrm{m}$ is delineated as the clay zone. Immediately underlying this layer is resistivity of $51.7 \Omega \mathrm{m}$ showing a sandy clay lithology that is suspected to be hydrocarbon plume (dark green) and polluted the groundwater to depth of 3 to $6 \mathrm{~m}$. It is pertinent to mention that the migration of the hydrocarbon was observed from lateral migrating pathways possible from the North West. Underlying the sandy layer resistivity distribution of $137 \Omega \mathrm{m}$ to $957 \Omega \mathrm{m}$ and layer thickness of 8 to $17.3 \mathrm{~m}$ is the possible depth for ground water

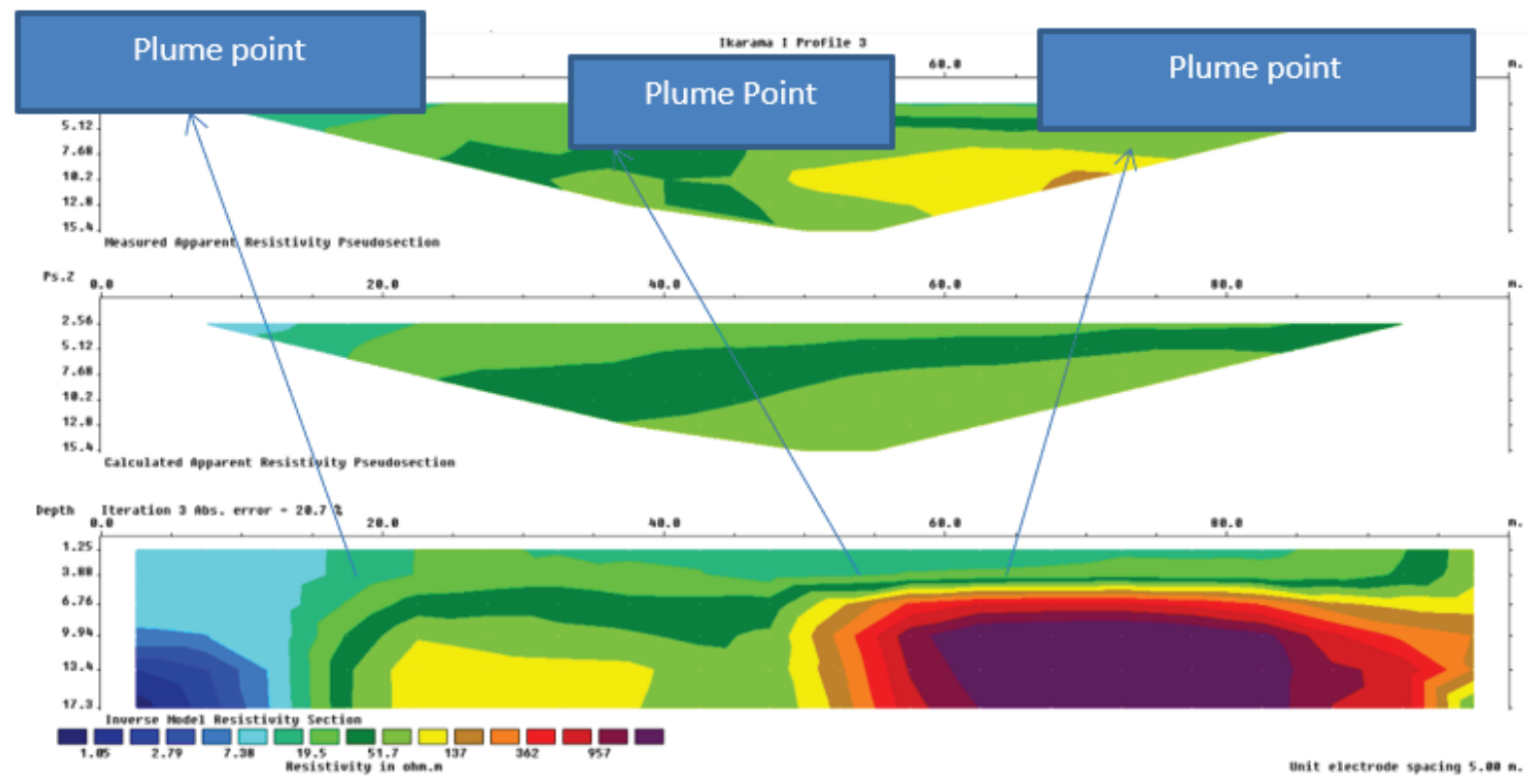

Fig 3: 2D profile of subsurface resistivity distribution at Ikarama

Table 2: 2D profile of subsurface resistivity distribution at Ikarama

\begin{tabular}{|l|l|l|l|l|l|}
\hline LAYERS & Resistivity & Depth range & Average thickness & Interpreted lithology & Remarks \\
\hline Layer 1 & 1.05 & $0-1.25$ & 1.25 & Topsoil & \\
\hline Layer 2 & $2.79-19.5$ & - & - & Clay & \\
\hline Layer 3 & 51.7 & $3-6$ & 3 & Sandy clay & HC Plume \\
\hline Layer 4 & $137-957$ & $8-17.3$ & 9.3 & Fine - coarse sand & \\
\hline
\end{tabular}

The subsurface 2D resistivity shows a resistivity distribution of $6.38 \Omega \mathrm{m}$ to $7479 \Omega \mathrm{m}$ and layer thickness of 1.25 to $17.3 \mathrm{~m}$ in Figure 3. A resistivity distribution of $6.38 \Omega \mathrm{m}(1.25 \mathrm{~m})$ as the top soil, resistivity distribution of $17.5 \Omega \mathrm{m}$ to $48.1 \Omega \mathrm{m}(5-7 \mathrm{~m})$ as clay layer, resistivity of $132 \Omega \mathrm{m}$ to $362 \Omega \mathrm{m}$ sandy clay depth of $8 \mathrm{~m}$, resistivity of $993 \Omega \mathrm{m}$ to $7479 \Omega \mathrm{m}$ is delineated as aquiferous layer. A resistivity of $17.5 \Omega \mathrm{m}$ is delineated as the suspected hydrocarbon plume with a depth between 3 to $7 \mathrm{~m}$. The indication of microbial load that facilitates the generation of organic acids which may have increased the conductivity values in the area this was consistent with previous studies interpreted as aged pollution (Atekwana et al., 2000: Estella and Elliot, 2009) 


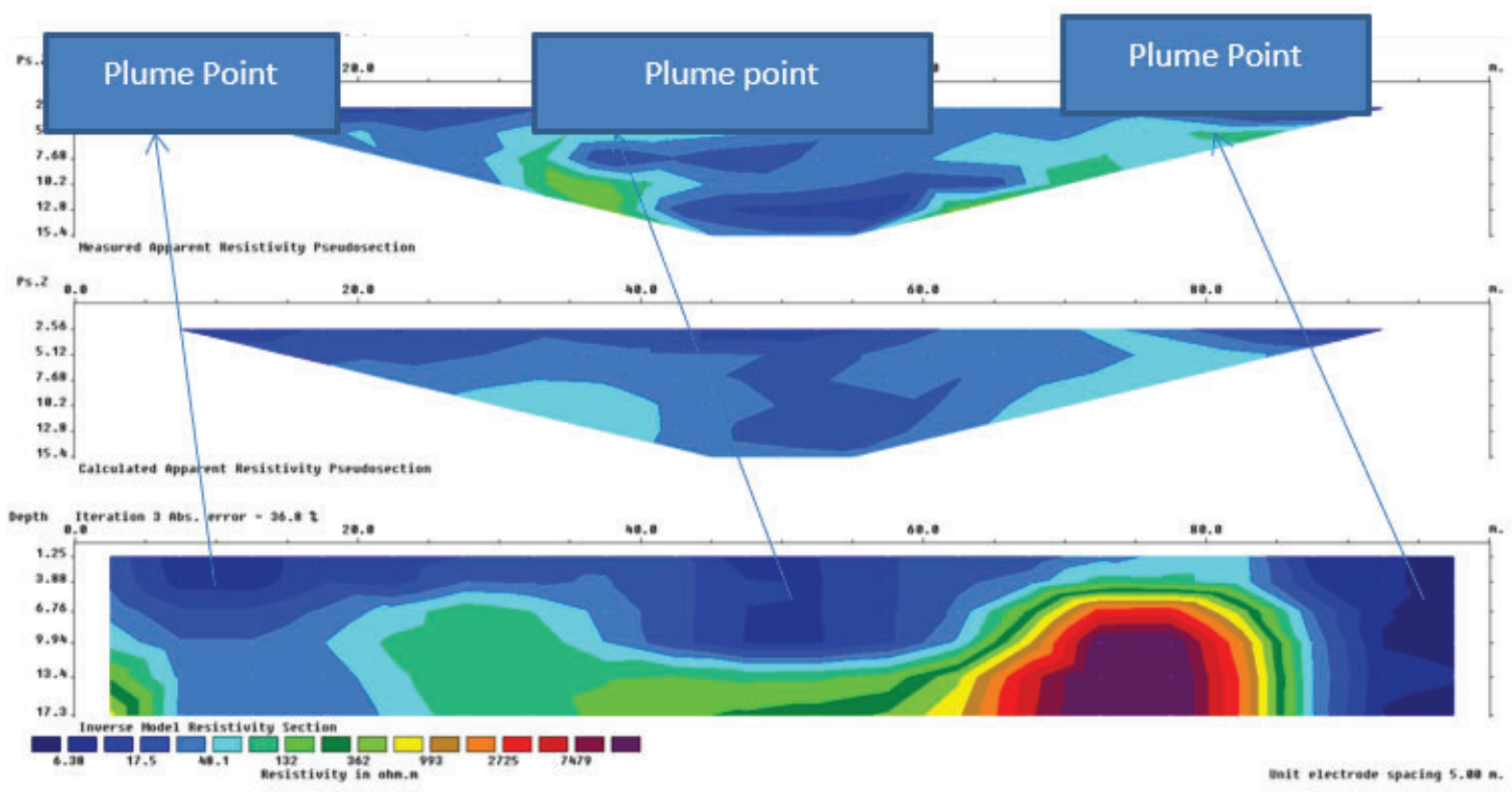

Fig 4: 2D profile of subsurface resistivity distribution at Ikarama

Table 3: 2D profile of subsurface resistivity distribution at Ikarama

\begin{tabular}{|l|l|l|l|l|l|}
\hline LAYERS & Resistivity & Depth range & Average thickness & Interpreted lithology & Remarks \\
\hline Layer 1 & 6.38 & $0-1.25$ & 1.25 & Topsoil & \\
\hline Layer 2 & $17.5-48.1$ & $3-7$ & 4 & Clay & Aged pollution \\
\hline Layer 3 & $132-362$ & 8 & $?$ & Sandy clay & \\
\hline Layer 4 & $993-7479$ & & & & aquiferous \\
\hline
\end{tabular}

The subsurface resistivity model of profile 10 in (Figure 5), a resistivity distribution of $6.54 \Omega \mathrm{m}$ to $943 \Omega \mathrm{m}$ at depth of 1.25 to $17.3 \mathrm{~m}$ was delineated in profile 10 . Resistivity of $6.54 \Omega \mathrm{m}$ was interpreted as top soil which is rich in organic materials; resistivity of $13.3 \Omega \mathrm{m}$ to $27.1 \Omega \mathrm{m}$ at depth of 1.25 to $6 \mathrm{~m}$ was interpreted as clay, $55.0 \Omega \mathrm{m}$ to $112 \Omega \mathrm{m}$ with a depth of $7 \mathrm{~m}$ implied sandy clay formation, while $228 \Omega \mathrm{m}$ to $943 \Omega \mathrm{m}$ indicated as aquiferous unit. Immediately below the top soil is a subsurface resistivity of $13.3 \Omega \mathrm{m}$ with depth of $5-6 \mathrm{~m}$ which indicates the presence of hydrocarbon plume. It is inferred that this layer has been affected by interaction of microbial load which manifested in the reduction of the resistivity values

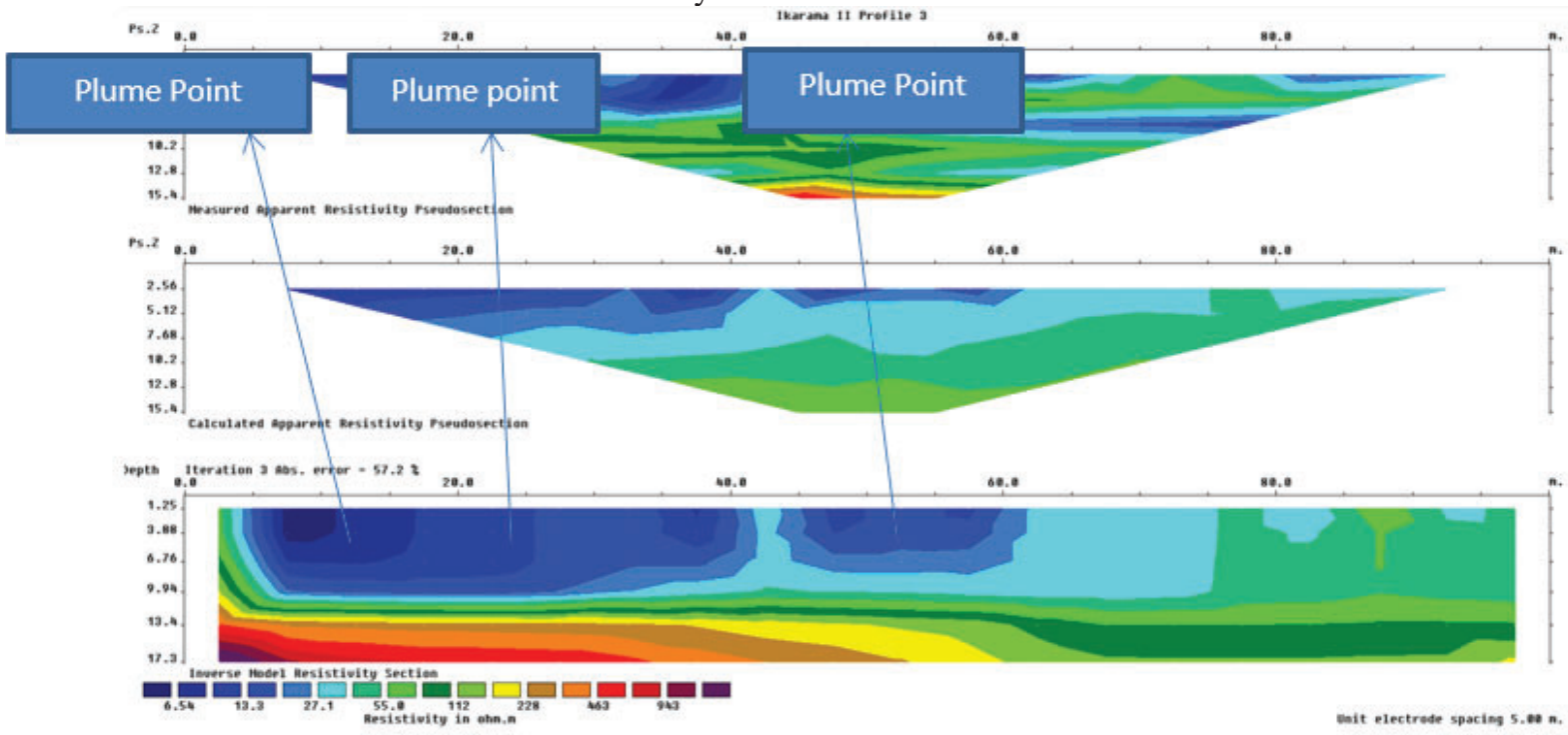

Fig 5: 2D profile of subsurface resistivity distribution at Ikarama 
Table 4: 2D profile of subsurface resistivity distribution at Ikarama

\begin{tabular}{|l|l|l|l|l|l|}
\hline LAYERS & Resistivity & Depth range & Average thickness & Interpreted lithology & Remarks \\
\hline Layer 1 & 6.54 & 1.25 & 1.25 & Topsoil & \\
\hline Layer 2 & $13.3-27.1$ & $1.25-6$ & 4.75 & Clay & HC Plume \\
\hline Layer 3 & $55-112$ & 7 & & Sandy clay & \\
\hline Layer 4 & $228-943$ & & & & aquiferous \\
\hline
\end{tabular}

Subsurface resistivity distribution of $11.8 \Omega \mathrm{m}$ to $198 \Omega \mathrm{m}(1.25$ to $17.3 \mathrm{~m})$ indicated in 2D profile 14 (Fig 6) of the impacted site was obtained. Resistivity of $17.6 \Omega \mathrm{m}$ to $39.4 \Omega \mathrm{m}$ was interpreted as clay, $59.0 \Omega \mathrm{m}$ to $88.2 \Omega \mathrm{m}$ as sandy clay, $132 \Omega \mathrm{m}$ to $198 \Omega \mathrm{m}$ as sandy layer. Suspected hydrocarbon plume was indicated with a resistivity of $11.8 \Omega \mathrm{m}$ with a depth of $6 \mathrm{~m}$.

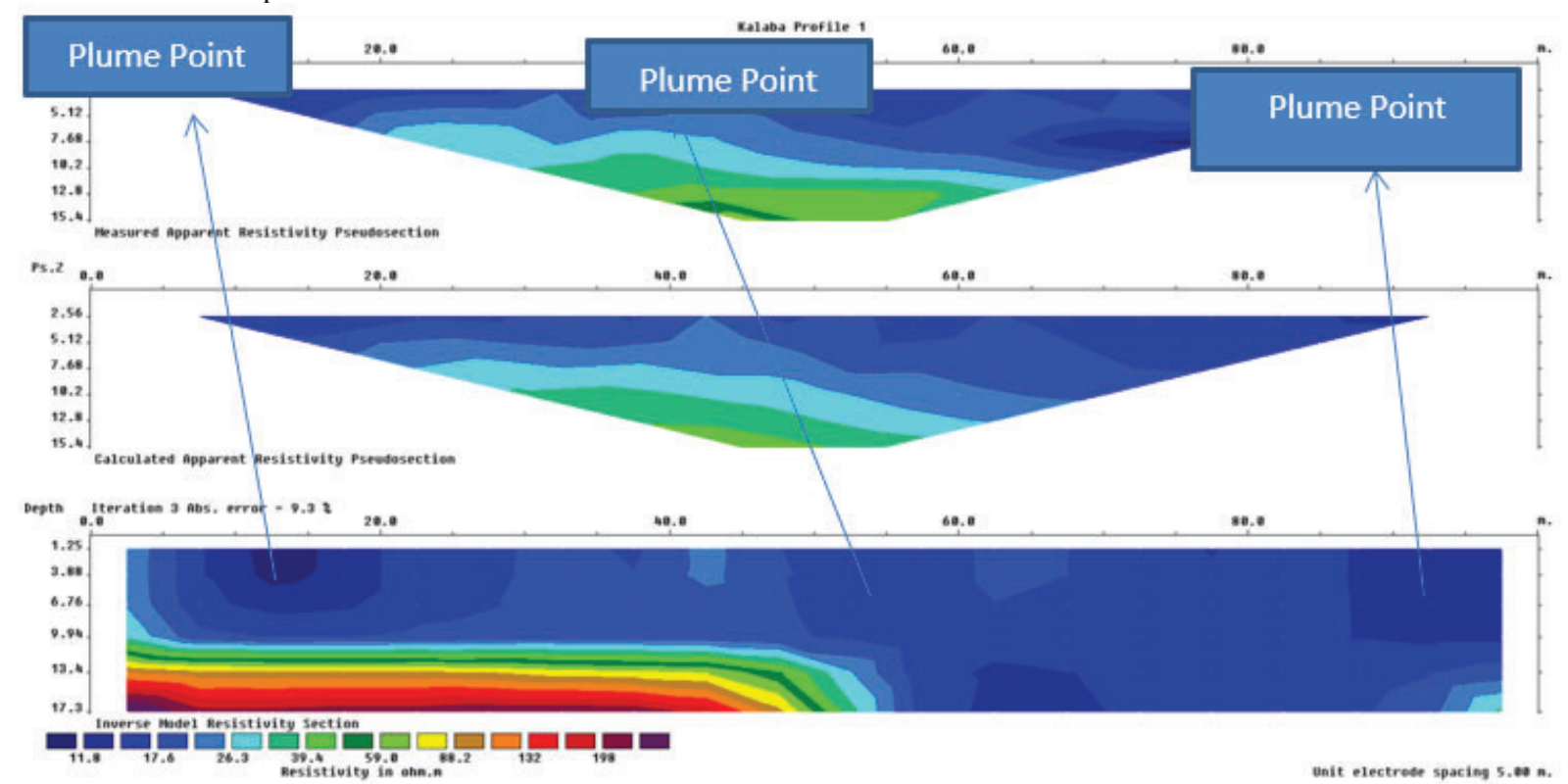

Fig 6: 2D profile of subsurface resistivity distribution at Kalaba

Table 5: 2D profile of subsurface resistivity distribution at Ikarama

\begin{tabular}{|l|l|l|l|l|l|}
\hline LAYERS & Resistivity & Depth range & Average thickness & Interpreted lithology & Remarks \\
\hline Layer 1 & 5.8 & 0.8 & 1.25 & Topsoil & Top soil \\
\hline Layer 2 & $17.6-39.4$ & $1.25-5$ & 3.75 & Clay & Aquiclude \\
\hline Layer 3 & 11.8 & 6 & 4.5 & Sandy clay & HC plume \\
\hline Layer 4 & $59.0-88.2$ & $6-10$ & 7.5 & Sandy clay & Aquitard \\
\hline Layer 5 & $132-198$ & $8-12$ & 9.5 & Sand & Water bearing \\
\hline
\end{tabular}

Subsurface resistivity distribution of $8.68 \Omega \mathrm{m}$ to $160 \Omega \mathrm{m}(0.5 \mathrm{~m}$ to $17.3 \mathrm{~m})$ (figure 7$)$ was delineated in profile 15 of the impacted site at Kalaba. A subsurface resistivity distribution of $8.68 \Omega \mathrm{m}$ is top soil; $13.2 \Omega \mathrm{m}$ to $30.3 \Omega \mathrm{m}$ with a depth of $2-3 \mathrm{~m}$ is clay; $45.9 \Omega \mathrm{m}$ to $69.6 \Omega \mathrm{m}$ sandy clay and $106 \Omega \mathrm{m}$ to $160 \Omega \mathrm{m}$ as sandy layer. A hydrocarbon plume was delineated at resistivity of $13.2 \Omega \mathrm{m}$ with a depth of $3 \mathrm{~m}$. Groundwater in the location is polluted with hydrocarbon to a depth of $2-5 \mathrm{~m}$. 


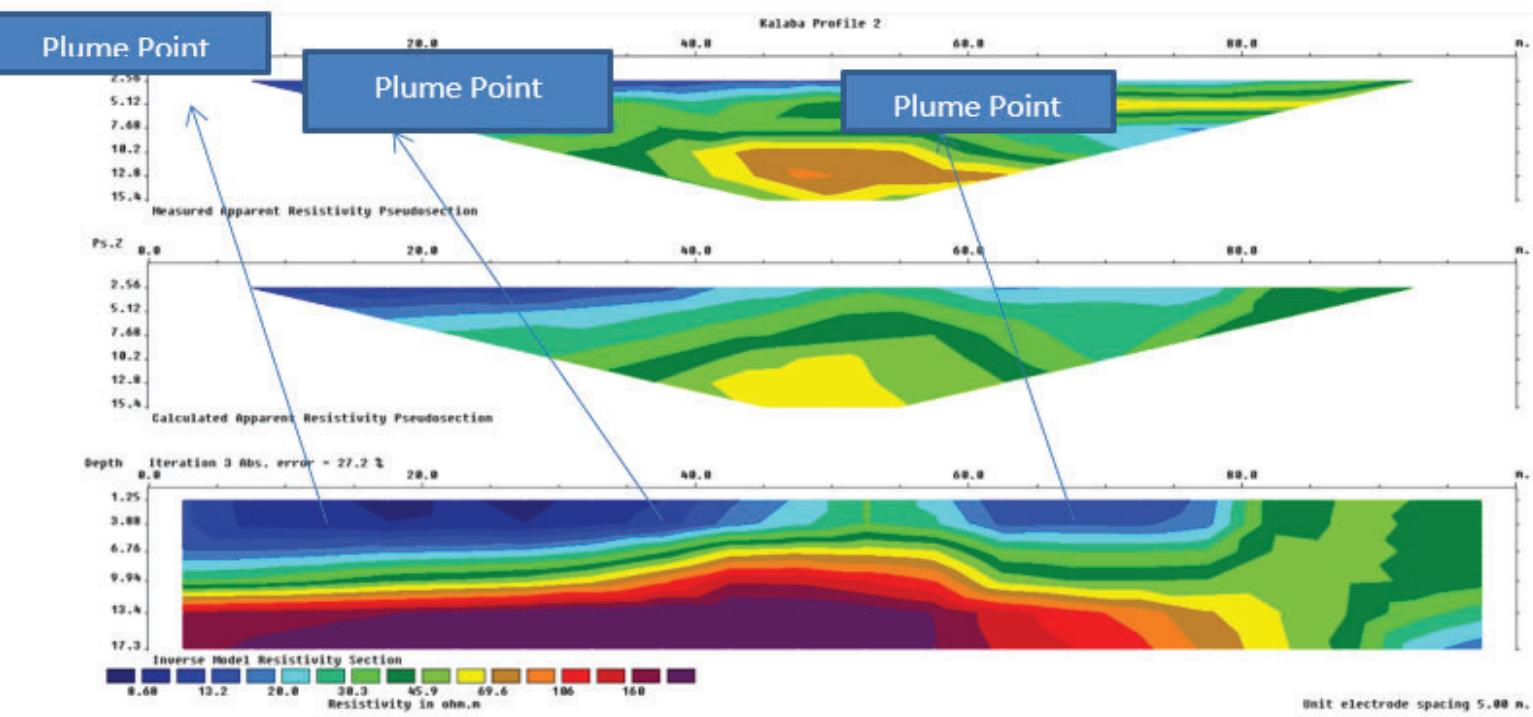

Fig 7: 2D profile of subsurface resistivity distribution at Kalaba

Table 6: 2D profile of subsurface resistivity distribution at Kalaba

\begin{tabular}{|l|l|l|l|l|l|}
\hline LAYERS & Resistivity & Depth range & Average thickness & Interpreted lithology & Remarks \\
\hline Layer 1 & 8.68 & 0.9 & 0.9 & Topsoil & Top soil \\
\hline Layer 2 & $13.2-30.3$ & 2 & 2.75 & Clay & Aquiclude \\
\hline Layer 3 & 13.2 & 3 & 3 & Sandy clay & HC plume \\
\hline Layer 4 & $45.9-69.6$ & $4-6$ & 5.5 & Sandy clay & Aquitard \\
\hline Layer 5 & $106-160$ & $7-10$ & 9.5 & Sand & Water bearing \\
\hline
\end{tabular}

A subsurface resistivity distribution of $0.174 \Omega \mathrm{m}$ to $340 \Omega \mathrm{m}$ with depth variation of $0.5 \mathrm{~m}$ to $17.3 \mathrm{~m}$ (Figure 8 ) was delineated in the control site at Ikarama. Resistivity distribution of $0.37 \Omega \mathrm{m}$ to $3.55 \Omega \mathrm{m}$ is clay; resistivity of $7.54 \Omega \mathrm{m}$ is indicated as sandy clay, resistivity of $16.0 \Omega \mathrm{m}$ to $34.0 \Omega \mathrm{m}$ as sand formation. The suspected plume was delineated at depth of $3 \mathrm{~m}$ with resistivity of $34.0 \Omega \mathrm{m}$. It is pertinent to say that from Figure 8 and 9 were models generated as control sites to probe the hydrocarbon impacted sites. In comparison with the hydrocarbon impacted sites. One difference that was established is that the resistivity values decreases with depth. For instance, a resistivity of $34.0 \Omega \mathrm{m}$ is showing as the highest resistivity with a depth variation of $1.5 \mathrm{~m}$ to $3.5 \mathrm{~m}$ which is interpreted as top soil. The fidelity of the results proves consistent in line with the analogy of resistivity values at non petroleum prone environment.

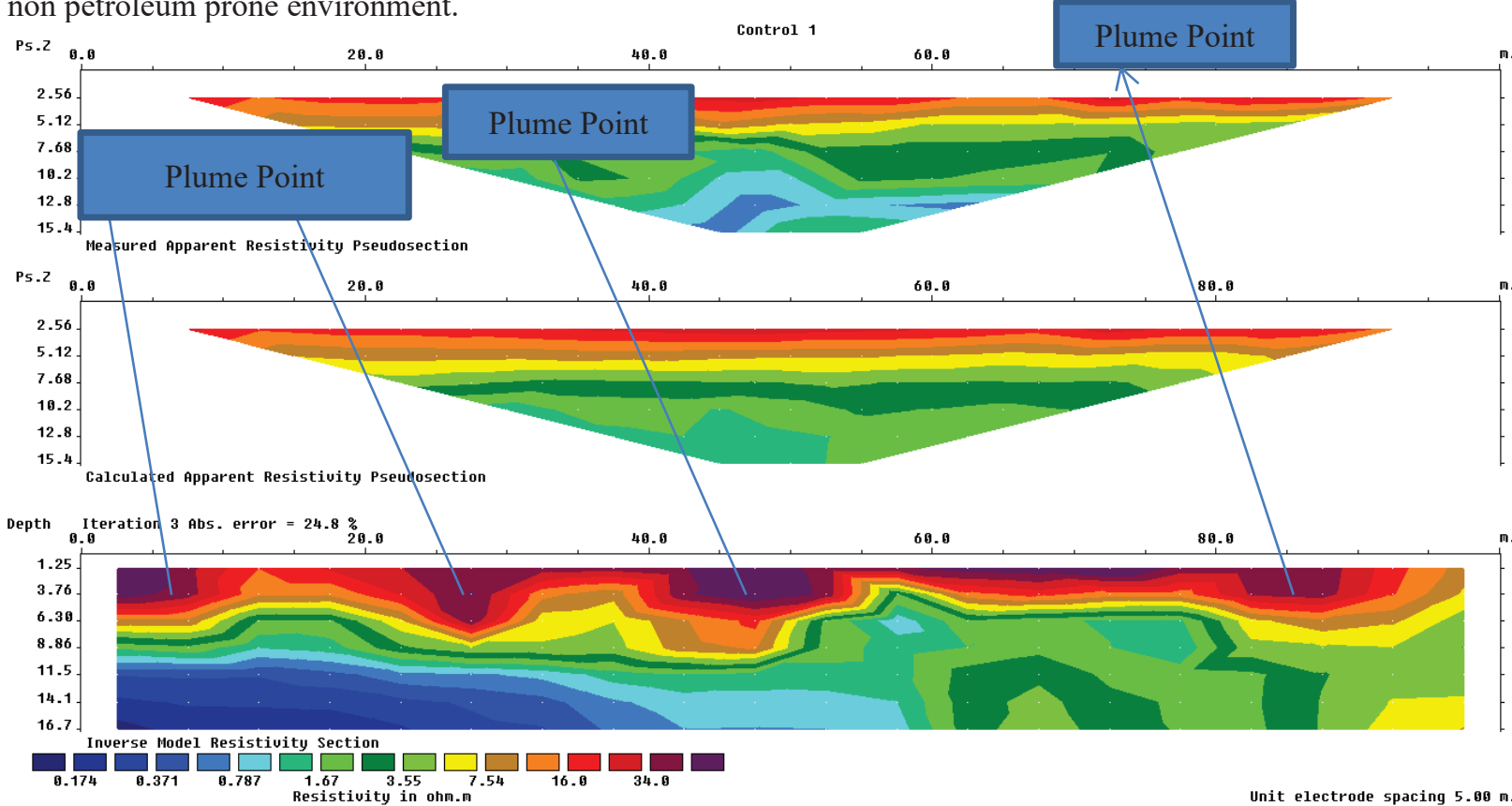

Fig 8: 2D profile of subsurface resistivity distribution at control site Ikarama 
Table 7: 2D profile of subsurface resistivity distribution at Control site Ikarama

\begin{tabular}{|l|l|l|l|l|l|}
\hline LAYERS & Resistivity & Depth range & Average thickness & Interpreted lithology & Remarks \\
\hline Layer 1 & 0.174 & 11 & 8.5 & Sandy layer & Water bearing \\
\hline Layer 2 & $0.371-1.67$ & 7 & 2.75 & Sandy clay & Aquitard \\
\hline Layer 3 & $1.67-3.55$ & $4.5-6$ & 5.5 & clay & Aquiclude \\
\hline Layer 4 & 7.54 & 3 & 3 & clay & Suspected plume \\
\hline Layer 5 & $16.8-34.0$ & $1.25-2.25$ & 1.5 & Top soil & Top soil \\
\hline
\end{tabular}

The subsurface resistivity distribution of $22.4 \Omega \mathrm{m}$ to $3184 \Omega \mathrm{m}$ with depth of $0.5 \mathrm{~m}$ to $17.3 \mathrm{~m}$ was delineated in profile 17 (Fig 9) of the control site. Resistivity distribution of $22.4 \Omega \mathrm{m}$ to $91.7 \Omega \mathrm{m}$ and depth of $9 \mathrm{~m}-17.3 \mathrm{~m}$ indicated sandy layer, $185 \Omega \mathrm{m}$ to $375 \Omega \mathrm{m}$ with depth of $6-8 \mathrm{~m}$ is sandy clay, $758 \Omega \mathrm{m}$ to $1534 \Omega \mathrm{m}$ with depth of 3$5 \mathrm{~m}$ is clay, resistivity of $3183 \Omega \mathrm{m}$ and depth of 0 to $2.5 \mathrm{~m}$ is interpreted as top soil. The suspected plume was delineated at depth of $0.5 \mathrm{~m}$ to $2 \mathrm{~m}$ with high restive zone of $3184 \Omega \mathrm{m}$.

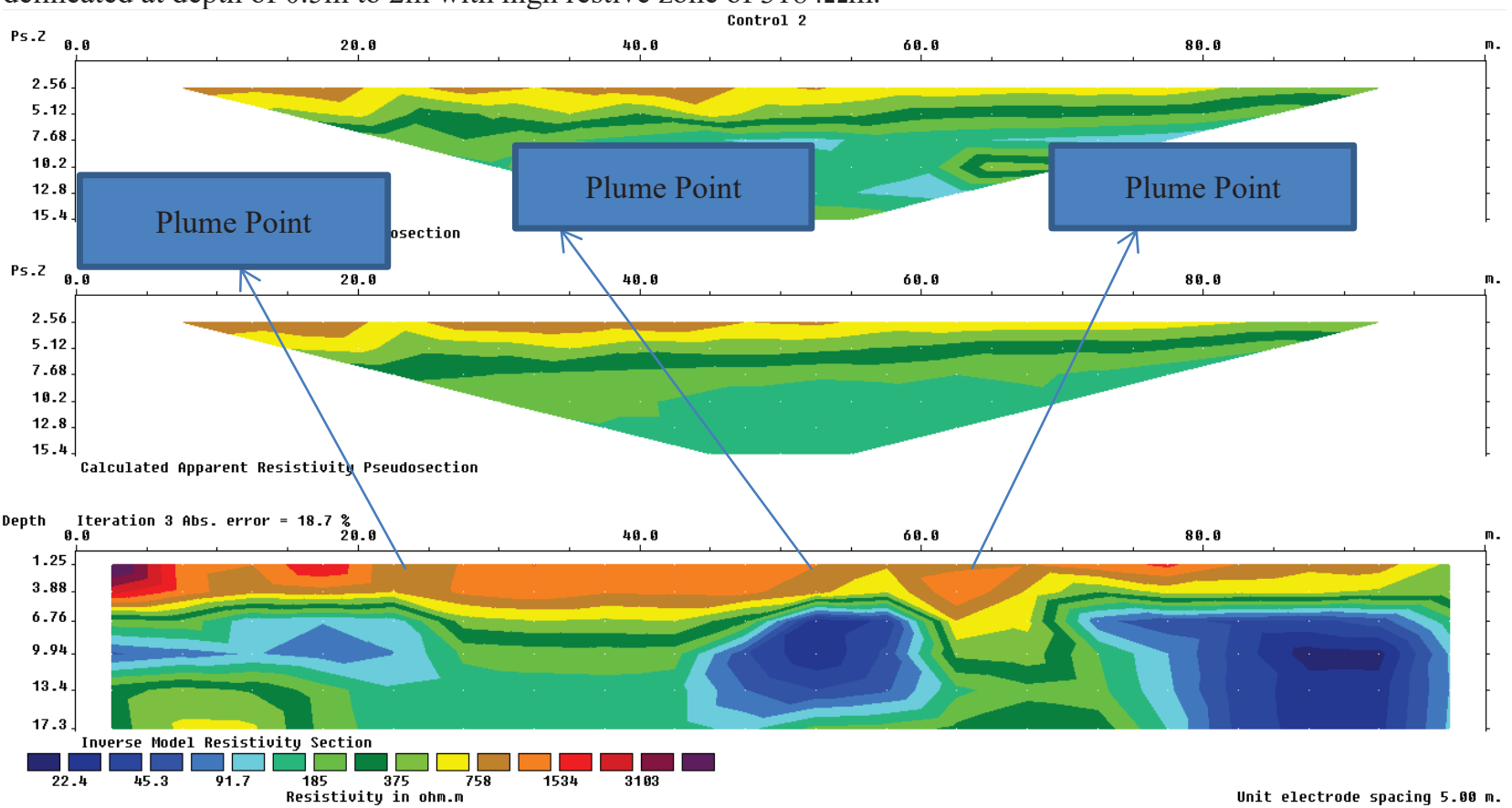

Fig 9: 2D profile of subsurface resistivity distribution at control site Kalaba

Table 8: 2D profile of subsurface resistivity distribution at Control site Kalaba

\begin{tabular}{|l|l|l|l|l|l|}
\hline LAYERS & Resistivity & Depth range & Average thickness & Interpreted lithology & Remarks \\
\hline Layer 1 & $22.4-91.7$ & $9-17.3$ & 7.5 & Sandy layer & Water bearing \\
\hline Layer 2 & $185-375$ & $6-8$ & 4.5 & Sandy clay & Aquitard \\
\hline Layer 3 & $758-1534$ & $3-5$ & 2.5 & clay & Aquiclude \\
\hline Layer 4 & 3183 & 2.5 & 1.5 & Top soil & Top soil \\
\hline Layer 5 & 3183 & 2 & 2 & clay & HC \\
\hline
\end{tabular}

\section{Conclusion}

The characterization of oil spill sites in Ikarama and Kalaba, Bayelsa State using electrical resistivity tomography (2D) method was ascertained. The study carefully examined various depths of hydrocarbon contamination. The 2D models indicated appreciable hydrocarbon contamination at depth range of $0 \mathrm{~m}$ to $5 \mathrm{~m}$. The delineated depths of contamination using surface geophysics attested the contaminant origin from hydrocarbon spills and other sources. Hence, the contaminant will continually leach vertically due to gravity and horizontally by advection into the groundwater reservoirs except the pollution is removed. Bioremediation and excavation methods are recommended in the area to restore green environment.

\section{References}

Adepelumi, A.A., Solanke, A.A., Sanusi, O.B., and Shallanga, A.M. (2006). Model tank electrical resistivity characterization of LNAPL migration in a clayey sand formation. Environ Geol, vol. 50, 1221-1233.

Atekwana, E.A., Sauck W.A., Abdel, A.G., and Werkema, D.D. (2000), Investigation of geo-electric signatures at a hydrocarbon contaminated site. Journal of Applied Geophysics vol 44; pp. 167-180 
Estella, A. A., and Elliot, A.A. (2009). Geophysical signatures of microbial activity at Hydrocarbon contaminated sites. A review, Journal Survey Geophysics (2010), 31; pp. 247-283

Etu-Efeotor, J.O., and Michalski, A. (1989) Geophysical investigation for groundwater in parts of the eastern Niger Delta. Journal of mining and geology vol 25 (1-2), pp. 51-54

Frankl, F.J and Cordy, E.A (1967). The Niger Delta oil province-recent developments onshore and offshore proceedings of the seventh World Petroleum Congress April 2-9, 1967, Mexico, pp 195-209

Offodile, M.E. (1992). Groundwater Study and Development in Nigeria. $2^{\text {nd }}$ edition. Mecon Geology, Ltd, Jos $453 \mathrm{p}$.

Sauck, W.A. (2000). A Model for the resistivity Structure of LNAPL Plumes and their Environs in Sandy Sediments. Journal of Applied geophysics. Vol 44; pp. 151-165

Sauck, W.A., Atekwana, E.A., and Nash, M.S. (1998). High conductivities associated with LNAPL plume imaged by integrated geophysical techniques. Journal of Environmental and Engineering Geophysics. vol 2 203-212

Short, K.C, and Stauble, A.J (1967). Outline of the geology of Onitsha, Owerri and Benue provinces. Geological Survey of Nigeria. Bullentin vol. 21 survey of Nigeria, 26-27.

Udom, G.J., Esu, E.O., and Ekwere, S.J. (1998). Quality status of groundwater in Calabar Municipality, South Eastern Nigeria. Global jour. of Pure and Appl. Sci. 4(2): 163-169

Weber, K.J and Daukoru, E.M (1975). Petroleum geology of Niger-Delta Proceedings of Ninth World Petroleum Congress, V.2 Geology: London, Applied Science Publishers, Ltd. Pp91-104

Werkema, D.D., Atekwana, E.A., Endres, A.L., Sauck, W.A., and Cassidy, D.P. (2003). Investigating the geoelectrical response of hydrocarbon contamination undergoing bio-degradation; geophysical research letters, 30, doi; 10.1029/2003GL017346, 49-1-49-4 